\title{
PENGARUH PEMBERIAN KOMUNIKASI, INFORMASI DAN EDUKASI (KIE) PADA IBU HAMIL PRIMIGRAVIDA TERHADAP PEMILIHAN KEPUTUSAN PERSALINAN NORMAL DI RUMAH SAKIT IMELDA PEKERJA INDONESIA (IPI) MEDAN TAHUN 2018
}

\author{
1. Sarida Surya Manurung; ${ }^{2}$.Jhenny Nurafni \\ 1. Dosen Prodi S-1Keperawatan, STIKes Imelda, Jalan Bilal Nomor 52 Medan; \\ 2. Alumni STIKes Imelda \\ E-mail: sarida.manurung1@gmail.com
}

\begin{abstract}
ABSTRAK
Persalinan adalah suatu peroses pengeluaran hasil konsepsi (janin dan plasenta) yang telah cukup bulan atau hidup diluar kandungan melalui jalan lahir atau melalui jalan lain, dengan bantuan atau tanpa bantuan (kekuatan sendiri). Persalinan normal adalah peroses pengeluaran janin yang terjadi pada kehamilan cukup bulan 37-42 minggu lahir sepontan tanpa komplikasi baik ibu maupun janin. Proses dimulai dengan adanya kontraksi persalinan sejati, yang ditandai dengan perubahan serviks secara progresif dan diakhiri dengan kelahiran plasenta. Salah satu penyebab ibu hamil primigravida yang tidak mengetahui pemilihan keputusan persalinan yang akan diambil salah satu dari faktor petugas kesehatan karena tidak memberikan informasi yang jelas pada ibu pra bersalin tentang pemilihan keputusan yang akan diambil. Persalinan ini bertujuan untuk melihat dan mengetahui pemilihan keputusan persalinan yang benar setelah diberi komunikasi, informasi dan edukasi di RSU IPI Medan Tahun 2018. Penelitian ini menggunakan Quasy eksperimen design tanpa pembanding, dengan populasi berjumlah 61 orang perbulan dan pengambilan sampel dengan metode non probability sampling menggunakan accidental sampling. Teknik analisa data dengan menggunakan analisa data univariate dan bivariate dengan taraf signifikan 95\% (_<0,05). Hasil penelitian ini menunjukkan bahwa adanya pengaruh yang signifikan antara pemberian komunikasi, informasi dan edukasi terhadap pemilihan keputusan persalinan dengan nilai $P=0,000 \pm \leq 0,05$ di RSU (IPI) Medan tahun 2018. Berdasarkan hasil penelitian diharapkan kepada petugas kesehatan dan peneliti dapat memahami dan meningkatkan pemberian KIE pada ibu hamil pra bersalin di wilayah kerja RSU (IPI) Medan.
\end{abstract}

Kata Kunci: Pemberian Komunikasi, Informasi Dan Edukasi, Ibu Hamil Primigravida, Pemilihan Keput usan Persalinan Normal.

\section{PENDAHULUAN}

Persalinan adalah kejadian yang berakhir dengan pengeluaran bayi yang cukup bulan atau hampir cukup bulan, disusul dengan pengeluaran placenta dan selaput janin dari tubuh ibu.Berdasarkan Survey Demografi Kesehatan Indonesia (SDKI) pada tahun 2011 angka

kematian

ibu di Indonesia tercatat 226 orang/100.000

kelahiran hidup.Angka tersebut lebih rendah dari angka kematian ibu (AKI) ditahun sebelumnya tercatat mencapai 300 orang /10.000 kelahiran hidup.Angka-angka diatas masih menunjukkan bahwa angka kematian ibu (AKI) di Indonesia masih cukup tingi walaupun dari tahun ke tahun terdapat penurunan.
Menurut survey kesehatan rumah tangga (2013) Penyebab langsung kematian ibu $90 \%$ terjadi pada saat persalinan dan segera persalinan penyebab langsung kematian ibu adalah perdarahan $28 \%$, ekslamsi $24 \%$, infeksi $11 \%$, partus lama 5 $\%$, dan abortus $5 \%$, penyebab tidak langsung kematian ibu antara lain kurang energy kronis pada khamilan $37 \%$ dan anemia pada kehamilan $4 \%$. Di Indonesia kematian ibu (AKI) dan angka kematian bayi s (AKB) masih tinggi dibandingkan dengan Negara ASEAN lainnya.Menurut data Survey Demografi Kesehatan Indonesia (SDKI) tahun 2010 angka kematian ibu (AKI) 228/100.000 kelahiran hidup dan angka kematian bayi (AKB) 34/100.000 kelahiran hidup. Pada tahun 2010-2015 angka kematian ibu (AKI) yang dilaporkan 
disumatra utara mengalami penurunan dari 32 8/100.000 kelahiran hidup menjadi 93/100.00 0 kelahiran hidup, sedangkan angka kematian ibu (AKB) disumatra utara turun dari 21/100.000 menjadi 20,22/100.000 kelahiran hidup (Dinkes sumut, 2015).

Berdasarkan survey awal yang dilakukan peneliti di Rumah Sakit Imelda Pekerja Indonesia Medan, data dari rekam medik menunjukkan jumlah pasien persalinan normal yang dirawat pada bulan Januari sampai Desember 2017 sebanyak 729 pasien $(38,8 \%)$ sedangkan paien dengan operasi caesarea $1150(61,2 \%)$ (Sirs Rs, 2017

). Demografi yang mempengaruhi ibu hamil memilih dalam tindakan Sectio caesarea meliputi faktor biologis (usia, pekerj aan, pendidikan, pengetahuan), faktor social (kurang dukungan dan kepastian eknomi), serta faktor sekunder yang berasal dari pengal aman melahirkan sebelumnya dengan ratarata pasien per bulan 96 pasien sedangkan normal 61 pasien.

Solusi yang sudah dilakukan petugas kes ehatan kepada ibu dalam pengambilan keputu san persalinan normal yaitu pemberian komunikasi, informasi dan edukasi (KIE), komunikasi yang baik berarti bahwa pihak terlibat secara aktif yaitu antara petugas kesehatan dan ibu pra persalinan sehingga akan baik untuk mengambil setiap keputusan. Dari uraian diatas, maka selanjutnya penulis tertarik untuk meneliti permasalahan tersebut dengan judul “ Pengaruh Komunikasi, informasi dan Edukasi (KIE) pada Ibu hamil primigravida Terhadap Pemilihan Keputusan Persalinan di Rumah Sakit Imelda Pekerja Indonesia Medan tahun 2018”.

\section{Rumusan Masalah}

Apakah ada pengaruhpemberian komuni kasi, informasi dan edukasi(KIE) pada Ibu hamil primigravida Terhadap Pemilihan Keputusan Persalinan Normal di Rumah Saki t Imelda Pekerja Indonesia Medan tahun 2018.

\section{Tujuan Penelitian Tujuan Umum}

Tujuan dilakukan penelitian ini adalah u ntuk mengetahui pengaruh pemberian komun ikasi, informasi dan edukasi (KIE) pada Ibu $h$ amil primigravida Terhadap Pemilihan Keput usan Persalinan di Rumah Sakit Imelda Pekerja Indonesia Medan tahun 2018.

\section{Tujuan khusus}

a. Untuk mengetahui apakah ada pengaruh pemberian komunikasi, informasi dan edukasi(KIE) pada ibu terhadap pemilihan keputusan persalinan di RSU Imelda Pekerja Indonesia Medan.

b. Untuk mengetahui tingkat pengetahuan i bu tentang pemilihan keputusan yang baik tentang persalinan di RSU Imelda Pekerja Indonesia Medan.

\section{Manfaat Penelitian}

Penelitian ini diharapakan akan dapat memberikan banyak manfaat berbagai pihak yaitu :

1. Bagi Responden

Sebagai bahan masukan dan sumber pengetahuan untuk menambah wawasan serta pengetahuan keluarga tentang persalinan normal dan komplikasi persalinan Sectio Cesarea.

2. Bagi Masyarakat Sebagai bahan masukan dan membantu program promosi kesehatan untuk penyuluhan keluarga dan ibu dengan pemilihan keputusan bersalin.

3. Bagi Rumah Sakit Imelda Pekerja Indonesia Medan

Hasil penelitian dapat digunakan sebagai masukan kepada pihak Rumah Sakit Imelda Pekerja Indonesia Medan untuk memperjelas pada ibu yan $\mathrm{g}$ akan memilih keputusan dalam persali nan, diharapakan dapat berkonstribusi da lam meningkatkan status kesehatan masyarakat.

4. Bagi peneliti selanjutnya Sebagai sumber pengetahuan bagi peneliti selanj utnya untuk menambah wawasan serta $p$ engetahuan penulis tentang pengaruh pemberian komunikasi dan edukasi terhadap ibu dalam pemilihan persalinan normal.

5. Bagi Institusi

Hasil penelitian dapat dijadikan referensi untuk peneliti selanjutnya.

\section{METODE \\ Jenis dan Desain Penelitian}

Penelitian ini menggunakan kuantitatif yaitu metode penelitian yang berlandaskan pada filsafat positivisme, digunakan untuk meneliti pada populasi atau sampel tertentu, pengumpulan data menggunakan instrument penelitian, analisis data bersifat kuantitatif/sta 
tistik dengan tujuan untuk menguji hipotesis yang telah ditetapkan (Sugiyono, 2013). Jenis penelitian yang digunakan dalam penelitian ini Quasy eksperimen design tanpa pembanding .Dengan pendekatan One Group Pre Test-Post Test yang hanya mempergunakan kelompok ekspe rimen saja, tanpa kelompok control (pembanding).penelitian ini pengujian pertama (pre test) yang memungkinkan peneliti dapat menguji perubahan-perubahan yang terjadi setelah adanya eksperimen (program). Penelitian ini bertujuan untuk mengetahui pengaruh pemberian komunikasi, informasi dan edukasi (KIE) pada ibu hamil terhadap pemilihan keputusan persalinan normal di RSU Imelda Pekerja Indonesia Medan.
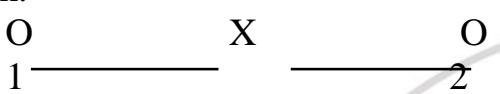

O1 :Pretest: sebelum diberi komunikasi, informasi dan edukasi (KIE)

O2 : posttest : sesudah diberi komunikasi, informasi dan edukasi (KIE)

$\mathrm{X}$ : Intervensi : diberi penyuluhan komunikas $i$, informasi dan edukasi tentang pemilihan keputusan persalinan.

\section{Lokasi dan Waktu Penelitian}

Lokasi penelitian dengan judul Pengaruh Pemberian Komunikasi, Informasi

Dan Edukasi (Kie) Pada Ibu Hamil Primigravida Terhadap Pemilihan Keputusan Persalinan Normal Dirumah Sakit Imelda Pekerja Indonesia (IPI) Medan Tahun 2018, al asan peneliti memilih memilih Rumah

Sakit Umum Imelda Pekerja Indonesia sebaga i tempat penelitian karena Rumah Sakit Umum Imelda Pekerja Indonesia memilki jarak yang tidak jauh dari tempat tinggal peneliti dan di Rumah Sakit Umum Imelda pekerja Indonesia memilki pasien yang Cukup Untuk menjadi sampel dalam penelitian ini mengenai pasien kanker yang menjalani tindakan kemoterapi. Penelitian ini akan dilakukan pada april 2018-juli 2018.

\section{Populasi}

Populasi dalam penelitian ini adalah ibu hamil primigravida di ruang BKIA RSU Imelda Pekerja Indonesia Medan. Dengan jumlah keseluruhan pasien 729 pada tahun 2017 maka dari itu peneliti mengambil populasi dari jumlah rata-rata dengan jumlah 61 pasien per bulan.

\section{Sampel dan Teknik Sampling}

Sampel adalah sebagian besar dari jumlah dan karakteristik yang dimiliki oleh populasi

(Notoatmodjo, 2012). Sampel dalam penelitia $\mathrm{n}$ ini ibu hamil primigravida di ruang BKIA di RSU Imelda Pekerja Indonesia Medan. De ngan teknik pengambilan sampel adalah Non probability Sampling dengan metode accidental sampling.

\section{Teknik Pengumpulan Data}

Data dikumpulkan langsung dengan menggunakan kuesioner yang diajukan secara tertulis kepada responden untuk mendapatkan jawaban tentang pemilihan keputusan persalinan pada ibu hamil primigravida.

\section{Variabel Penelitian}

Variabel adalah ukuran atau ciri yang dimiliki oleh anggota-anggota kelompok yang berbeda-beda dengan yang dimiliki oleh kelompok yang lain (Notoadmojo,2010), variable yang digunakan dalam penelitian ini meliputi :

1. Variabel bebas adalah variabel yang mempengaruhi atau menjadi sebab perubahannya atau timbulnya variabel dependen (sugiono, 2011), variabel bebas dari penelitian ini adalah pemilihan keputusan persalinan ibu.

2. Variabel terikat (dependen variabel) Variabel terikat merupakan variabel yang dipengaruhi atau yang menjadi akibat, karena adanya variabel bebas (sugiyono, 2011), variabel terikat dalam variabel penelitian ini adalah mengguna kan metode komunikasi dan edukasi seb elum persalinan.

\section{Defenisi Operasional}

Menurut Nazir (2014) defenisi operasional dalah suatu defenisi yang diberikan kepada suatu variabel atau konstrak dengan cara memberikan operasi onal yang diperlukan untuk mengukur ko nstrak atau variable tersebut. Defenisi ope rasional dan cara pengukuran yang akan digunakan dalam penelitian ini dapat dilihat pada tabel dibawah ini : 
Tabel 1. Definisi Operasional Penelitian

\begin{tabular}{|c|c|c|c|c|c|c|}
\hline No & $\begin{array}{c}\text { Variabel yang } \\
\text { diteliti }\end{array}$ & Defenisi operasional & Alat ukur & Kriteria & $\begin{array}{l}\text { Skala } \\
\text { ukur }\end{array}$ & Skor \\
\hline \multirow[t]{2}{*}{1.} & & \multicolumn{4}{|l|}{ Variabel independen } & \\
\hline & $\begin{array}{l}\text { Komunikasi, } \\
\text { informasi dan } \\
\text { edukasi (KIE) }\end{array}$ & $\begin{array}{l}\text { Kegiatan tatap muka } \\
\text { antara } 2 \text { orang atau } \\
\text { lebih yang hanya } \\
\text { bertujuan } \\
\text { memberikan } \\
\text { informasi untuk } \\
\text { membantu pihak lain } \\
\text { mengambil keputusan } \\
\text { dan diberikan pada } \\
\text { ibu hamil } \\
\text { primigravida } \\
\text { trimester ketiga. Data } \\
\text { dapat melalui } \\
\text { observasi kepada } \\
\text { responden }\end{array}$ & kuesioner & _ & Ordinal & - \\
\hline \multirow[t]{2}{*}{2.} & & \multicolumn{4}{|l|}{ Variabel dependen } & \\
\hline & $\begin{array}{l}\text { Pemilihan } \\
\text { keputusan } \\
\text { persalinan }\end{array}$ & $\begin{array}{l}\text { Proses yang } \\
\text { digunakan untuk } \\
\text { memilih suatu } \\
\text { tindakan untuk } \\
\text { memilih suatu } \\
\text { tindakan sebagai } \\
\text { pemecahan masalah }\end{array}$ & kuesioner & $\mathrm{Ya}: 2$ & Ordinal & $\begin{array}{l}\text { Baik : } \\
39-52 \\
\text { Buruk } \\
: 26- \\
38\end{array}$ \\
\hline
\end{tabular}

\section{Aspek Pengukuran}

Untuk mengukur pemilihan keputusan persalinan sebanyak 26 pertanyaan dengan penilaian terhadap jawaban Ya skor 2 dan Tidak skor 1, sehingga skor tertinggi adalah 52 dan skor terendah adalah 26. Untuk mengukur digunakan rumus Sudjana:

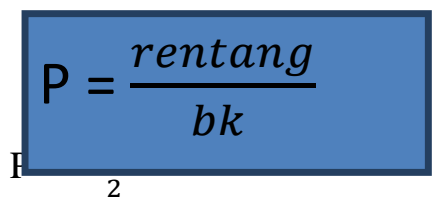

$\mathrm{P}=\frac{26}{2}=13$

$\mathrm{P}=13$

Ket :

$\mathrm{P} \quad=$ Nilai yang dicari

Rentang $=$ skor tertinggi - skor terendah

BK = Banyaknya kategori

Maka pemilihan keputusan persalinan dikatakan:

Baik : 39-52
Buruk : 26-38

\section{Instrumen Penelitian}

Instrumen pengumpulan data adalah alat-alat yang digunakan untuk pengumpulan data (Notoatmodjo, 2012). Peneliti menggunakan instrumen berupa kuesioner. Kuesioner merupakan salah satu alat pengumpulan data yang berisi daftar pertanyaan dan bentuk penjabaran variabelvariabel yang terlibat dalam tujuan penelitia $\mathrm{n}$ dan hipotesis (Notoatmodjo, 2012).

Kuesioner ini menggunakan jenis kuesioner checklist dan tanda silang yang merupakan daftar yang berisi pertanyaan atau pernyataan yang akan diamati dan responden memberikan jawaban dengan tanda checklist $(\sqrt{ })$ dan tanda silang $(X)$ sesuai dengan hasil yang diinginkan.

\section{Pengolahan Data}

Setelah data terkumpul, maka peneliti melakukan pengolahan data melalui 
beberapa tahap. Tahap pertama melakukan editing untuk memeriksa atau mengevaluasi kelengkapan dan konsistensi dari semua jaw aban responden terhadap kuesioner yang diberikan responden. Kemudian melakukan coding dari setiap jawaban untuk memudahkan peneliti, setelah itu memberi scoring untuk menentukan skor atau nilai baik skor 2 dan buruk skor 1 dari pemilihan keputusana persalinan. Setelah selesai memberikan penilaian kemudian dilakukan Tabulasi dengan memasukkan semua jawaban kedalam tabel untuk mempermudah analisa data.

\section{Teknik Analisa Data \\ Analisa Univariat}

Analisa univariat digunakan untuk mendeskripsikan distribusi frekuensi dari masing-masing variabel penelitian. Analisa ini digunakan untuk memperoleh gambaran pada masing-masing variabel independen yang meliputi pemberia $\mathrm{n}$ komunikasi dan edukasi dalam pemilihan persalinan normal.

\section{Analisa Bivariat}

Analisis ini untuk mengetahui pengaruh pemberian komunikasi, informasi dan edukasi (KIE) pada ibu hamil primigravida terhadap pemilihan keputusan persalinan di Rumah Sakit Imelda Pekerja Indonesia Medan tahun 2018. Dengan menggunakan uji Wilcoxon.

\section{HASIL}

\section{Hasil Univariat}

Setelah dilakukannya penelitian dengan judul "pengaruh pemberian komunikasi, informasi dan edukasi pada ibu hamil primig ravida terhadap pemilihan keputusan peralin an normal di Rumah Sakit Imelda Pekerja Indonesi (IPI) Medan tahunn 2018" terhadap 30 responden yang diambil dengan cara accidental sampling maka diperoleh hasil sebagai berikut :

\section{Data Umum}

Tabel 2. Distribusi Karakteristik Responden Berdasarkan Umur Tentang Pemilihan Keputusan Persalinan di Rumah Sakit Imelda Pekerja Indonesia Medan Tahun 2018.

\begin{tabular}{cccc}
\hline No & $\begin{array}{c}\text { Karakter } \\
\text { istik }\end{array}$ & $\begin{array}{c}\text { Freku } \\
\text { ensi }\end{array}$ & $\begin{array}{c}\text { Persen } \\
\text { tase \% }\end{array}$ \\
\hline 1 & $17-20$ & 1 & 3,3 \\
\hline 2 & $21-24$ & 14 & 46,7 \\
\hline 3 & $25-28$ & 7 & 23,3 \\
\hline 4 & $29-32$ & 8 & 26,7 \\
\hline $\begin{array}{c}\text { Juml } \\
\text { ah }\end{array}$ & & $\mathbf{3 0}$ & $\mathbf{1 0 0}$ \\
\hline
\end{tabular}

Berdasarkan tabel 2 diatas terlihat bahwa mayoritas responden yang interval usianya 21-24 tahun sebanyak 14 orang (47 $\%)$, sedangkan minioritas responden yang interval usianya 17-20 tahun sebanyak 1 orang $(3 \%)$.

Tabel 3. Distribusi Karakteritik Responden Berdsarkan Pendidikan TentangPemilihan Keputusan Persalinan di Rumah Sakit Imelda Pekerja Indonesia Medan Tahun 2018.

\begin{tabular}{cccc}
\hline No & Karakteristik & Frekuensi & Persentase \\
\hline 1 & SD & 2 & 6,7 \\
\hline 2 & SMP & 10 & 33,3 \\
\hline 3 & SMA & 11 & 36,7 \\
\hline 4 & D3 & 0 & 0 \\
\hline 5 & SARJANA & 7 & 23,3 \\
\hline & Jumlah & $\mathbf{3 0}$ & $\mathbf{1 0 0}$ \\
\hline
\end{tabular}

Berdasarkan tabel diatas dapat dilihat bahwa bahwa mayoritas responden berdasarkan pendidikan SMA sebanyak 11 orang $(37 \%)$ sedangkan minoritas responden berdasarkan pendidikan D3 sebanyak $0(0 \%)$.

Tabel 4. Distribusi karakteristik responden berdasarkan pekerjaan tentangpemilihan keputusan persalinan di Rumah Sakit Imelda Pekerja Indonesia Medan Tahun 2018.

\begin{tabular}{cccc}
\hline No & Karakteristik & Frekuensi & $\begin{array}{c}\text { Persentase } \\
\mathbf{\%}\end{array}$ \\
\hline 1 & PNS & 7 & 23,3 \\
\hline 2 & IRT & 15 & 50,00 \\
\hline 3 & $\begin{array}{c}\text { Pegawai } \\
\text { swsata }\end{array}$ & 3 & 10,0 \\
\hline 4 & Wiraswasta & 5 & 16,7 \\
\hline & Jumlah & $\mathbf{3 0}$ & $\mathbf{1 0 0}$ \\
\hline
\end{tabular}


Berdasarkan tabel 4 diatas dapat dilihat bahwa mayoritas responden berdasarkan pekerjaan ibu rumah tangga sebanyak 15 orang $(50 \%)$, sedangkan minoritas responde n berdasarkan pekerjaan wiraswasta sebanya k 5 orang $(17 \%)$.

\section{Sebelum (pre) dan sesudah (post) diberi komunikasi, informasi dan edukasi di Rumah Sakit Imelda Pekerja Indonesia (IPI) Medan tahun 2018.}

Tabel 5. Hasil Sebelum (Pre) Dilakukan Pemberian Komunikasi, Informasi Dan Edukasi (pretest).

\begin{tabular}{|c|c|c|c|c|c|}
\hline \multirow{3}{*}{ No } & \multirow{3}{*}{ Pemberian KIE } & \multicolumn{4}{|c|}{ Pre Test } \\
\hline & & \multicolumn{2}{|c|}{ Ya } & \multicolumn{2}{|c|}{ Tidak } \\
\hline & & $\mathbf{N}$ & $\%$ & $\mathbf{n}$ & $\%$ \\
\hline 1. & Mengetahui tentang persalinan & 22 & 73,3 & 8 & 26,7 \\
\hline 2. & Apakah ibu akan memilih persalinan normal & 2 & 6,7 & 28 & 93,3 \\
\hline 3. & Sudah mengetahui macam-macam persalinan & 5 & 16,7 & 25 & 83,3 \\
\hline 4. & Ibu mengetahui yang dimaksud persalinan normal & 4 & 13,3 & 26 & 86,7 \\
\hline 5. & Ibu mengetahui yang dimaksud persalinan normal & 21 & 70,05 & 9 & 30,3 \\
\hline 6. & $\begin{array}{l}\text { Sebelumnya pernah berkonsultasi dengan dokter tentang } \\
\text { pemilihan keputusan persalinan }\end{array}$ & 8 & 26,7 & 5 & 16,7 \\
\hline 7. & persalinan normal sangat menakutkan bagi ibu & 20 & 66,7 & 10 & 33,3 \\
\hline 8. & Sebelum nya pernah diberi KIE tentang pemilihan keputusan & 5 & 16,7 & 25 & 83,3 \\
\hline 9. & Ibu sudah mempersiapkan pada saat mau bersalin & 7 & 23,3 & 23 & 76,7 \\
\hline 10. & $\begin{array}{l}\text { Ibu mengetahui yang dianjurkan untuk menolong persalinan } \\
\text { adalah tenaga kesehatan }\end{array}$ & 6 & 20,0 & 24 & 80,0 \\
\hline 11. & Ibu mengetahui persalinan anak pertama lebih lama & 14 & 46,7 & 16 & 53,3 \\
\hline 12. & Ibu mengetahui lama kehamilan normal adalah 9 bulan & 20 & 66,7 & 10 & 33,3 \\
\hline 13. & $\begin{array}{l}\text { Pemilihan persalinan normal sangat dianjurkan oleh tenaga } \\
\text { medis }\end{array}$ & 10 & 33,3 & 20 & 66,7 \\
\hline 14. & $\begin{array}{l}\text { Keputusan persalinan caesarea dilakukan karena tidak } \\
\text { mengetahui tentang persalinan normal }\end{array}$ & 19 & 63,3 & 11 & 36,7 \\
\hline 15. & Tindakan operasi cesarean merupakan alternative bagi wanita & 24 & 80,0 & 6 & 20,0 \\
\hline 16 & Persalinan normal dianggapp sebagai persalinan yang sulit & 23 & 76,7 & 7 & 23,3 \\
\hline 17. & Persalinan normal membutuhkan penyembuhan yang lama & 22 & 73,3 & 8 & 26,7 \\
\hline 18. & ibu mengupayakan bahwa proses harus dalam kondisi normal & 4 & 13,3 & 26 & 86,7 \\
\hline 19. & Keputusan persalinan yang diambil adalah keputusan suami & 2 & 6.7 & 28 & 93.3 \\
\hline 20. & Persalinan sectio persalinaan yang diinginkan ibu & 13 & 43,3 & 17 & 56,7 \\
\hline 21. & $\begin{array}{l}\text { Ibu merasa ketakutan memilih persalinan normal Karena } \\
\text { mendengar cerita-cerita dari kerabat/teman }\end{array}$ & 22 & 73.3 & 8 & 26,7 \\
\hline 22. & $\begin{array}{l}\text { Ibu sudah mempersiapkan keperluan semenjak masa } \\
\text { kehamilan }\end{array}$ & 14 & 46,7 & 16 & 53,3 \\
\hline 23. & $\begin{array}{l}\text { Ibu mempercayai persalinan normal lebih baik daripada } \\
\text { caesarea }\end{array}$ & 15 & 50,0 & 15 & 50,0 \\
\hline 24. & $\begin{array}{l}\text { Ibu mengetahui bahwa usia ibu tidak ada resiko untuk } \\
\text { melahirkan }\end{array}$ & 9 & 30,0 & 21 & 70,0 \\
\hline 25. & $\begin{array}{l}\text { Ibu mengetahui persalinan yang ditangani selain tenaga } \\
\text { kesehatan sangat berbahya }\end{array}$ & 2 & 6,7 & 28 & 93,3 \\
\hline 26. & $\begin{array}{l}\text { Ibu selalu berunding dengan keluarga tentang persalinan yang } \\
\text { akan diambil }\end{array}$ & 6 & 20,0 & 24 & 80,0 \\
\hline
\end{tabular}


Tabel 6. Hasil Sesudah (Post) Dilakukan Pemberian Komunikasi, Informasi Dan Edukasi (pretest).

\begin{tabular}{|c|c|c|c|c|c|}
\hline \multirow{3}{*}{ No } & \multirow{3}{*}{ Pemberian KIE } & \multicolumn{4}{|c|}{ Post Test } \\
\hline & & \multicolumn{2}{|c|}{ Ya } & \multicolumn{2}{|c|}{ Tidak } \\
\hline & & $\mathbf{N}$ & $\%$ & $\mathbf{n}$ & $\%$ \\
\hline 1. & Mengetahui tentang persalinan & 25 & 83,3 & 5 & 16,7 \\
\hline 2. & Apakah ibu akan memilih persalinan normal & 28 & 93,3 & 2 & 6,7 \\
\hline 3. & Sudah mengetahui macam-macam persalinan & 29 & 96,7 & 1 & 3,3 \\
\hline 4. & Ibu mengetahui yang dimaksud persalinan normal & 29 & 96,7 & 1 & 3,3 \\
\hline 5. & Ibu mengetahui yang dimaksud persalinan normal & 29 & 96,7 & 1 & 3,3 \\
\hline 6. & $\begin{array}{l}\text { Sebelumnya pernah berkonsultasi dengan dokter tentang } \\
\text { pemilihan keputusan persalinan }\end{array}$ & 25 & 83,3 & 5 & 16,7 \\
\hline 7. & persalinan normal sangat menakutkan bagi ibu & 14 & 46,7 & 16 & 53,3 \\
\hline 8. & Sebelum nya pernah diberi KIE tentang pemilihan keputusan & 26 & 86,7 & 4 & 13,3 \\
\hline 9. & Ibu sudah mempersiapkan pada saat mau bersalin & 27 & 90,00 & 3 & 10,0 \\
\hline 10. & $\begin{array}{l}\text { Ibu mengetahui yang dianjurkan untuk menolong persalinan } \\
\text { adalah tenaga kesehatan }\end{array}$ & 29 & 96,7 & 1 & 3,3 \\
\hline 11. & Ibu mengetahui persalinan anak pertama lebih lama & 27 & 90,0 & 3 & 10,0 \\
\hline 12. & Ibu mengetahui lama kehamilan normal adalah 9 bulan & 27 & 90,0 & 2 & 6,7 \\
\hline 13. & $\begin{array}{l}\text { Pemilihan persalinan normal sangat dianjurkan oleh tenaga } \\
\text { medis }\end{array}$ & 21 & 70,0 & 9 & 30,0 \\
\hline 14. & $\begin{array}{l}\text { Keputusan persalinan caesarea dilakukan karena tidak } \\
\text { mengetahui tentang persalinan normal }\end{array}$ & 12 & 40,0 & 18 & 60,0 \\
\hline 15. & Tindakan operasi cesarean merupakan alternative bagi wanita & 9 & 30,0 & 21 & 70,0 \\
\hline 16 & Persalinan normal dianggapp sebagai persalinan yang sulit & 9 & 30,0 & 21 & 70,0 \\
\hline 17. & Persalinan normal membutuhkan penyembuhan yang lama & 17 & 56,7 & 13 & 43,3 \\
\hline 18. & ibu mengupayakan bahwa proses harus dalam kondisi normal & 24 & 80,0 & 6 & 20,0 \\
\hline 19. & Keputusan persalinan yang diambil adalah keputusan suami & 29 & 96,7 & 1 & 3,3 \\
\hline 20. & Persalinan sectio persalinaan yang diinginkan ibu & 19 & 63,3 & 11 & 36,7 \\
\hline 21. & $\begin{array}{l}\text { Ibu merasa ketakutan memilih persalinan normal Karena } \\
\text { mendengar cerita-cerita dari kerabat/teman }\end{array}$ & 24 & 80,0 & 6 & 20,0 \\
\hline 22. & $\begin{array}{l}\text { Ibu sudah mempersiapkan keperluan semenjak masa } \\
\text { kehamilan }\end{array}$ & 27 & 90,0 & 3 & 10,0 \\
\hline 23. & $\begin{array}{l}\text { Ibu mempercayai persalinan normal lebih baik daripada } \\
\text { caesarea }\end{array}$ & 23 & 76,7 & 7 & 23,3 \\
\hline 24. & $\begin{array}{l}\text { Ibu mengetahui bahwa usia ibu tidak ada resiko untuk } \\
\text { melahirkan }\end{array}$ & 22 & 73,3 & 8 & 26,7 \\
\hline 25. & $\begin{array}{l}\text { Ibu mengetahui persalinan yang ditangani selain tenaga } \\
\text { kesehatan sangat berbahya }\end{array}$ & 27 & 90,0 & 3 & 10,0 \\
\hline 26. & $\begin{array}{l}\text { Ibu selalu berunding dengan keluarga tentang persalinan yang } \\
\text { akan diambil }\end{array}$ & 28 & 93,3 & 2 & 6,7 \\
\hline
\end{tabular}

\section{Hasil Bivariat}

Pada penelitian ini data yang diperoleh dapat dianalisa dengan analisis bivariate yait $\mathrm{u}$ untuk mengetahui pengaruh pemberian ko munikasi, informasi dan edukasi (KIE) pada ibu hamil primigravida terhadap pemilihan $\mathrm{k}$ eputusan persalinan normal di Rumah Sakit Imelda Pekerja Indonesia tahun 2018.
Berdasarkan penelitian ,pemberian komunikasi, informasi dan edukasi (KIE) pada ibu hamil primigravida terhadap pemilihan keputusan persalinan dapat dilihat pada tabel hasil uji Wilcoxon di bawah ini. 
Tabel 7. Hasil Uji Wilcoxon.

\begin{tabular}{|c|c|c|c|c|}
\hline $\begin{array}{l}\mathbf{N} \\
\mathbf{0}\end{array}$ & $\begin{array}{c}\text { Variabe } \\
1\end{array}$ & $\begin{array}{c}\text { Jumla } \\
\text { h (n) }\end{array}$ & $\begin{array}{c}\text { Median } \pm \\
\text { interquartil } \\
\text { e range }\end{array}$ & $\begin{array}{c}P . \\
\text { value }\end{array}$ \\
\hline 1. & $\begin{array}{l}\text { Sebelum } \\
\text { (pre- } \\
\text { test) }\end{array}$ & 30 & $35,00 \pm 3,0$ & $\begin{array}{c}0.000 \\
1\end{array}$ \\
\hline 2. & $\begin{array}{l}\text { Sesudah } \\
\text { (post- } \\
\text { test) }\end{array}$ & 30 & $47,00 \pm 3,0$ & \\
\hline
\end{tabular}

Ket $: \mathrm{P}<0,05$ maka ada pengaruh pemberian KIE sebelum dengan sesudah Berdasarkan tabel diatas pemberian KIE pada ibu hamil primigravida sangat berpengaruh. Sebelum diberi KIE ibu yang tidak mengetahui persalinan yang akan dipilih sebanyak 26 orang (88,7 \%) ,sedangkan sesudah diberi KIE sebanyak 30 orang $(100 \%)$.

\section{PEMBAHASAN}

\section{Pemilihan Keputusan Persalinan Pada} Ibu Hamil Primigravida

Hasil penelitian yang dilakukan peneliti didapatkan bahwa responden berubah persep si tentang pemilihan keputusan yang akan diambil setelah diberi komunikasi, informasi dan edukasi pada ibu hamil primigravida. Sebelum (pre) ibu hamil primigravida diberi komunikasi, informasi dan edukasi pemiliha $n$ keputusan persalinan, ibu tidak mengetahu i persalinan yang akan dipilih sebanyak 26 orang $(88,7 \%)$,sedangkan sesudah diberi KIE sebanyak 30 orang (100\%). Berdasarka $\mathrm{n}$ jawaban kuesioner yang didapatkan data $\mathrm{b}$ ahwa pemberian komunikasi, informasi dan edukasi (KIE) sangat membantu dalam pemi lihan keputusan persalinan pada ibu hamil pr imigravida sebelum bersalin. Petugas keseha tan juga mempengaruhi karena tidak membe rikan informasi yang jelas kepada ibu pra be rsalin tentang pemilihan keputusan yang akan diambil (Endang, 2015).

Sebelum diberi komunikasi, informasi dan edukasi klien ditanya tentang pemilihan apa yang akan diambil, persiapan yang sudah di siapkan oleh ibu untuk persali nan, dan alasan mengapa klien memilih pers alinan yang dipilih oleh klien dan diberi kuesioner untuk diisi yang akan diberi skor 1 = tidak dan skor 2 ya.

\section{Pengaruh Pemberian Komunikasi, Informasi Dan Edukasi (KIE)}

Hasil uji statistik dengan menggunakan uji Wilcoxcon didapatkan nilai $\mathrm{p}$ value sebesar $0,0001 \mathrm{P}<0,05$ yang artinya pe mberian komunikasi, informasi dan edukasi (KIE) ada pengaruh tentang pemilihan keputusan persalinan.

\section{KESIMPULAN}

Berdasarkan hasil penelitian dan pembahasan, penelitian ini menyimpulkan bahwa :

1. Sebagian besar klien dengan ketidaktah uan tentang pemilihan persalinan sebelu $\mathrm{m}$ (pre) diberikan komunikasi, informas i dan edukasi (KIE) memiliki tingkat pe ngetahuan yang

buruk/rendah di Rumah Sakit Imelda Pe kerja Indonesia (IPI) Medan dengan per sentase mencapai sebanyak 26 orang $(88,7 \%)$.

2. Ada pengaruh yang signifikan antara pemberian komunikasi, informasi dan edukasi (KIE) pada ibu hamil primigravida dengan pemilihan keputus an persalinan di Rumah Sakit Imelda Pekerja Indonesia (IPI) Medan. Hasil dari uji wilcoxson menunjukkan b esar nilai signifikansi (p) sebesar 0.000 . nilai signifikasin yang besar nya dibawah 0,05 mengindikasikan adanya pengaruh yang signifikan antara variabe 1 pemberian komunikasi, informasi dan edukasi (KIE) pada ibu hamil pimigravi da terhadap pemilihan keputusan persal inan.

\section{SARAN}

1. Bagi perawat di Rumah Sakit Imelda Pekerja Indonesia (IPI) Medan, perawat disarankan untuk memberikan komunika si, informasi dan edukasi sebelum melakukan persalinan dan memberikan perhatian lebih pada klien agar klien merasa bahwa mereka mendapatkan dukungan untuk semangat dan dipandan $\mathrm{g}$ berharga oleh ptugas kesehatan. Perawat juga seharusnya memberikan 
penjelasan-penjelasan tentang persalinan yang akan dipilih, persiapan persalinan, macam-macam persalinan dan komplikasi-komplikasi yang terjadi jika persalinan dilakukan dengan operasi sectio caesarea. Perawat sebagai pihak yang paling banyak melakukan kontak dengan pasien dan keluarga yang mengantar diharapkan mengedukasi pasien untuk memberikan motivasi kepd a klien dan memperbanyak interaksi social bagi klien untuk memilih persalin an normal sebagai alternative yang baik untuk ibu jika tidak ada indikasi-indikasi yang mengharuskan untuk melakukan tidakan sectio caesarea sehingga klien $\mathrm{m}$ emiliki peran dan dapat mengembalikan semngat untuk proses pemilihan keputusan yang baik.

2. Bagi klien ibu hamil primigravida, klien disarankan untuk memilih persalinan normal jika tidak terjadi indikasi yang mengharuskan untuk persalinan operasi caesarea.

3. Bagi peneliti selanjutnya, supaya mamp u mengembangkan penelitian selanjutny a berdasarkan penelitian yang dilakukan peneliti saat ini untuk meneliti variabel lainyang terkait dengan pemberian komu nikasi, informasi dan edukasi (KIE) pada ibu hamil terhadap pemilihan keputusan persalinan atau variabel lainyang belum diteliti.

\section{DAFTAR PUSTAKA}

Depkes RI. (2008). Pedoman Pelaksanaan K egiatan Komunikasi, Informasi, Edukas $i$ (Kie) Kesehatan Reproduksi Untuk Pe tugas Kesehatan Ditingkat Pelayanan Dasar. Jakarta : Departemen Kesehatan RI.

Green, L.w. (2005). Health Program Planning, Educational and Ecological
Approach, Mayfield Publishing Company California.

Hidayat, Asri \& Sujiyatini. (2016). Asuhan Kebidanan Persalinan. Yogyakarta : Nuha Medika.

Icesmi sukarni, Margaret ZH. (2015). Kehamilam, Persalinan, Nifas, Cetakan Kedua. Yogyakarta: Fitramaya.

Ina kuswanti, Fitria. (2015). Askeb II persalinan. Yogyakarta: Pustaka Pelajar.

Manuaba, Ida Bagus. (2012). Ilmu Kebidanan, Penyakit Kandungan Dan Keluarga Berencana Untuk Pendi dikan Bidan. Jakarta : EGC.

Mochtar, R., 2010, Synopsis Obsetri, jilid 1, EGC, Jakarta.

Mulyani, Deddy. (2007). Ilmu Komunikasi Remaja. Bandung: Rosdakarya.

Maksimus Ramses Lalongkop Thomas Alfai Edison. (2014). Komunikasi Terapeutik. Jakarta: Graha Ilmu.

Nazir, Moh. (2014). Metodologi Penelitian. Jakarta : Ghalia Indonesia.

Notoatmodjo, S. (2012). Promosi Kesehatan - Teori Dan Aplikasi. Cetakan II. Jakarta: Rineka Cipta.

Prakktiknya, A.W. (2008). Dasar-Dasar Metodologi Penelitian Kedokteran Dan Kesehatan. Jakarta: Rajagrafindo Persada.

Sarwono. (2010 lmu Kebidanan. Yogyakarta : Yayasan Bina Pustaka.

Siti tyastuti, dkk, (2010). Komunikasi dan Konseling dalam Pelayanan Kebidanan.Yogyakarta : Fitramaya.

Sujiyanti, dkk. (2017). Asuhan Kebidanan II Persalinan. Yogyakarta : Rohima Press.

Sugiyono. (2013). Metode Penelitian Kombinasi (Mixed Methods). Bandung: Alfabeta 